\title{
船舶推進用高温超電導モータの研究開発の状況
}

\author{
梅本 勝弥 ${ }^{*}{ }^{\dagger}$, 柳本 俊之*
}

\section{Current Status of Research \& Development of High-temperature Superconducting Motor for Ship Propulsion}

\author{
Katsuya UMEMOTO*` ${ }^{* \dagger}$ and Toshiyuki YANAMOTO*
}

\begin{abstract}
Synopsis: Although the application of superconductivity technologies to rotating machines has been studied since the 1970s, it has not yet been made practicable. However, due to the recent rapid improvements in high-temperature superconductor performance, high-temperature superconducting motors for ship propulsion are approaching a level where they can be utilized. In this article, the current status of R\&D on high-temperature superconducting motors for ship propulsion being developed by Kawasaki Heavy Industries Ltd. (KHI) and its cooperative research groups is reported. In particular, the aims, content and plans of two projects being led by KHI will be shown. The first one is the New Energy and Industrial Technology Development Organization (NEDO) energy-saving project, and the second one is the Japan Science and Technology Agency (JST) SInnovation project. Finally, a roadmap and further studies related to the practical application of high-temperature superconducting motors for ship propulsion are shown.
\end{abstract}

Keywords: high-temperature superconducting motor, ship propulsion, AC loss, cooling system

(Some figures in this article may appear in colour only in the electronic version)

\section{1. はじめに}

超電導技術の回転機械への応用は、1970 年代から研究 されているが、未だ実用化されていない。その理由として 様々なものが考えられるが、臨界電流や線材長といった超 電導線材の性能がコストと比較し、十分にメリットを生か せるレベルではなかったこと、超電導コイルの耐久性やク エンチ対策などへの技術的知見が不足していたこと、ま た、冷却システム等の付帯設備によるコスト増や信頼性に 対する知見が不足していたことなどが挙げられる。超電導 技術は究極技術である一方、その応用は既存機器の代替と なる場合が多く、当初より㛜しいコスト競争に晒されると いう不利な点がある。しかしながら、最近の高温超電導線 材の進歩により、そのようなコスト競争を乗り越え、新た な価值創造が見えるところまで来ているといえる。我が国 は、高温超電導線材の開発や製造において、世界の最先端 に位置しており、その成果を世界に先駆けて実用化してい くことは責務であろう。このように、高温超電導線材の性 能・コストの見通しが立ちつつある現状、超電導回転機技

\footnotetext{
Received March 27, 2012

* 川崎重工業株式会社 技術開発本部 技術研究所

干 673-8666 兵庫県明石市川崎町 1-1

1-1, Kawasaki-cho, Akashi, Hyogo 643-8666, Japan

† E-mail: umemoto_katsuya@khi.co.jp
}

術、冷却技術やコイル化技術などの周辺技術に関しても、 国内外の技術を結集し、早急に実用化レベルまで引き上げ ることが必要となってきている。

以上の背景のもと、川崎重工業株式会社（以下、当社と いう）は、2007 年度より船舶推進用高温超電導モータの 開発を本格化し、（独）新エネルギー・産業技術総合開発 機構（以下、NEDO という）のエネルギー使用合理化技 術戦略的開発事業として $1 \mathrm{MW}$ 級高温超電導モータの開 発を行った。2010 年度からは同機構の省エネルギー革新 技術開発事業として $3 \mathrm{MW}$ 高温超電導モータを開発中であ る。また、2009 年度からは（独）科学技術振興機構（以 下、JST という）戦略的イノベーション創出推進事業（Sイノベ）「大出力超伝導回転機器に向けたキーハードの開 発」にも参画し、大型超伝導回転機において必要となる要 素技術の開発を行っている。

本テーマ解説では、先ず、船舶推進用の高温超電導モー タのメリットを説明する。次に、上記の 2 事業の目的と位 置づけ、研究開発の現状を紹介する。最後に、高温超電導 モータの実用化までの道筋についての所見を述べる。

なお、本テーマ解説における語用として、JST S-イノベ 事業に関する記述では、本事業におけるこれまでの慣習を 踏襲し “超伝導”の表記を用いることとし、その他の部分 については“超電導”の表記を用いている。 


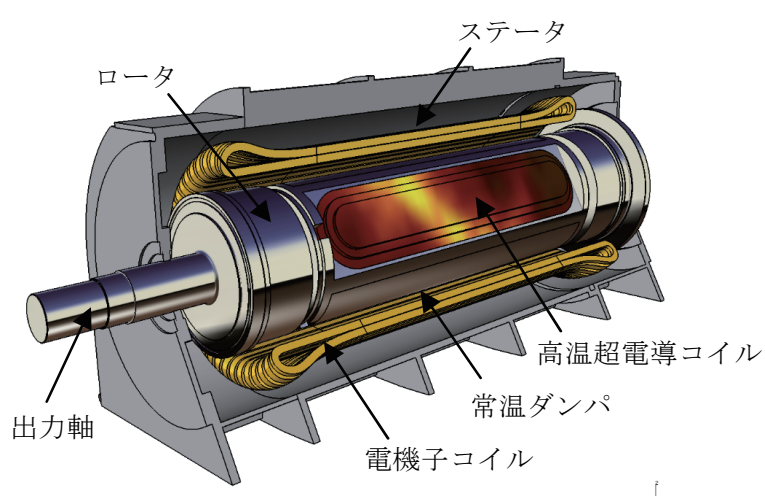

Fig. 1 Structure of megawatt-class superconducting motor.

\section{2. 船舶推進用高温超電導モータのメリット}

船舶推進用の高温超電導モータの性能的メリットとして は、“コンパクト性”と“高効率性”が挙げられる。

モータは界磁子と電機子で構成される。界磁子は永久磁 石もしくは電磁石により磁場を発生させる。電機子では、 電機子巻き線に外部から交流電力を供給することで磁場を 生じさせ、界磁子が発生した磁場と相互作用することでト ルク（回転力）を得る。Fig. 1 に当社が開発する高温超電 導モータの基本構成を示す。形式はオーソドックスなラジ アル型の界磁巻き線型同期電動機であり、直線部を有す “レーストラック型” 高温超電導コイルをロータ内に積層 することで界磁極を構成し界磁子としている。界磁子はト ルクを発生させながら回転するが、そのような状態におい て内部の超電導コイルは超電導状態を維持する必要がある ため、界磁極は常温ダンパと呼ばれる円筒状の特殊なクラ イオスタットに収納されている。一方、ステータ側である 電機子コイルには、通常の銅巻き線を使用している。界磁 子を超電導化すると永久磁石では達成できないような高磁 場が発生可能となり、モータの大幅なコンパクト化が達成 できる。Fig. 2 及び Fig. 3 には、当社が採用する構造の高 温超電導モータの出力と径及び重量の関係を低速の通常電 動機の同関係（商用量産電動機からの推定值）と比較した ものを示す。本図を見ると、電動機を超電導化することで 大幅なコンパクト化と軽量化が達成できることが理解でき る。なお、ここでは、高温超電導モータで使用する超電導 線材は、その将来性能として 300 A 級@77 K を考慮し、 冷却損を含む総合効率として 98～99\%を設定している。

\section{3. プロジェクトの目標と位置付け}

当社が中心となって実施する高温超電導モー夕開発関連 プロジェクト 2 件の目的と位置づけを紹介する。

\subsection{NEDO 省エネルギー革新技術開発事業}

NEDO 省エネルギー革新技術開発事業は、温室効果ガス 排出量を現状に比べて 2050 年までに半減するという長期 目標を実現のため経済産業省がかかげる「Cool Earth-エネ

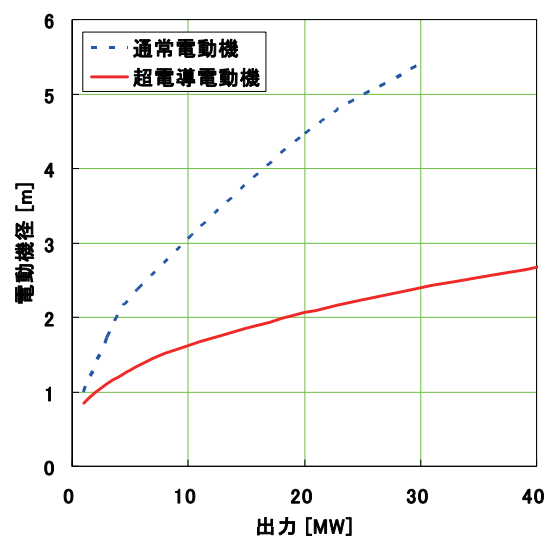

Fig. 2 Relationship between the motor radius and the motor output.

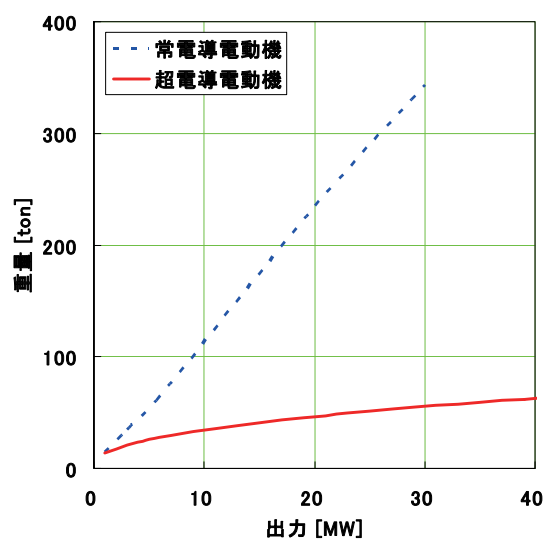

Fig. 3 Relationship between the motor weight and the motor output.

ルギー革新技術計画」の主旨に基づき、大幅な省エネル ギー効果を発揮する革新的なエネルギー使用合理化技術に 関する研究開発・実用化を推進することを目標としている。 当社を中心とする研究開発チームは、本事業の先導研究 フェーズに 2007 年度に応募し、「船舶用高温超電導モータ 内蔵ポッド推進システムの研究開発」（2007～2009年度） の採択を受けた。ここでは、内航船向けの1 MW級高温超 電導モータの開発を行った。次に、2010年度には、同事業 の実用化開発フェーズとして「船舶用高温超電導モータ内 蔵ポッド推進システム実用化のための研究開発」（2010～ 2012年度）の採択を受け、現在、内航船向けの3 MW高温 超電導モータの開発を行っている。それぞれのプロジェク トの体制およびスケジュールをTable 1に示す。

Table 1 Organization and schedule of the NEDO energy-saving project

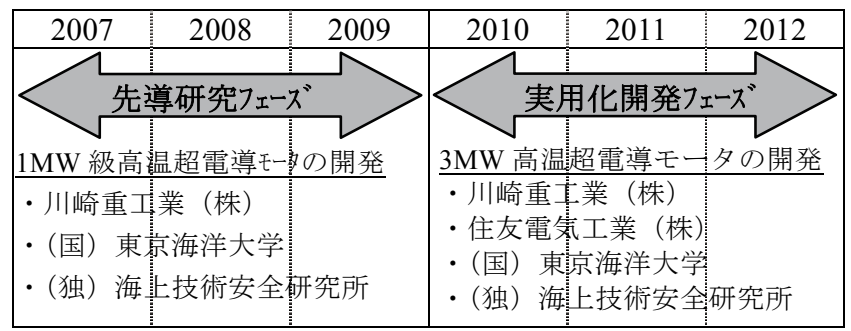


本事業では、メガワット級の高温超電導モータの設計を 行った上で、現状入手可能な高温超電導線材を使用して実 スケールの高温超電導モータを製作する。完成した高温超 電導モータに対し負荷試験による性能確認を行う。

また、ここでは、新しい舶用推進システムとして、「高 温超電導モータ内蔵ポッド推進システム」を提案している

(Fig. 6 参照)。舶用の推進システムを、従来のディーゼ ル直結型から電気推進システムに単純に積み替えると、機 械エネルギーから電気エネルギーへのエネルギー変換時の ロスが増大することで大幅な燃費増加を招く。しかしなが ら、ここで開発する高温超電導モータ内蔵ポッド推進シス テムでは、高温超電導モータの高効率性とそのコンパクト 性を生かした二重反転プロペラと船型改良の採用により、 従来の通常船型でのディーゼル直結型推進システムと比較 して、16\%以上の然費削減が可能との目処を、CFD (Computational Fluid Dynamics) 解析、縮尺模型船による 水槽試験及び運航データの解析結果より得ている ${ }^{1), 2)}$ 。

\subsection{JST 戦略的イノベーション創出推進事業 (S-イノベ)}

JST 戦略的イノベーション創出推進事業（S-イノベ）で は、産業創出の礎となる研究開発テーマを設定し、産学連 携の複数研究開発チームの下、基礎から実用化までの長期 一貫（最長 10 年間）した研究開発が進められている。

2009 年度の研究開発テーマの 1 つであった「超伝導シス テムによる先進エネルギー・エレクトロニクス産業の創 出」における 4 研究開発チームの 1 つとして、当社が参画 した「大出力超伝導回転機器に向けたキーハードの開発」が 採択された。本プロジェクトの体制およびスケジュールを Table 2 に示寸。ここでは、将来、大型外航船向け $20 \mathrm{MW}$ 級大出力超伝導モータを実現していくために特に重要と なってくるキーハードの研究開発を行っている。実施内容 は Fig. 4 に示すように船舶用大型超伝導回転機設計技術、 超伝導界磁コイル技術、超伝導コイル冷却技術に大別され ている。

本事業では、ステージ I （応用基礎研究及び要素技術の 研究開発）からスタートするのが通常であるが、本研究開 発チームは、NEDO プロジェクト等の先行研究での実績 を踏まえ、より実用化に近いステージII（要素技術の研究

Table 2 Organization and schedule of the JST S-innovation project

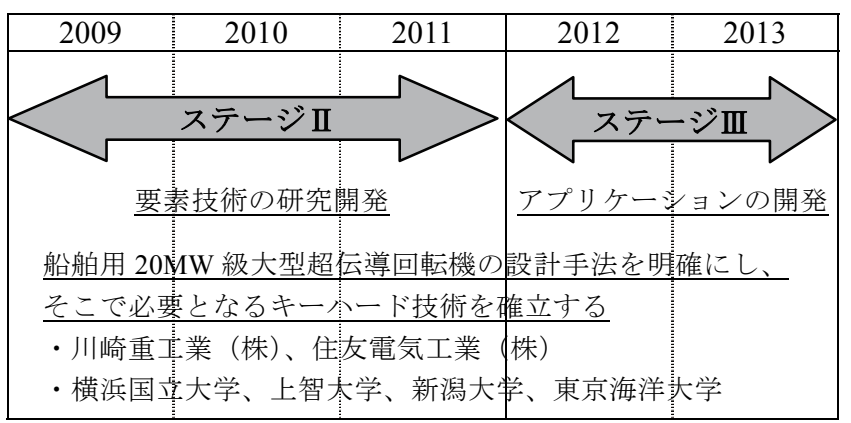

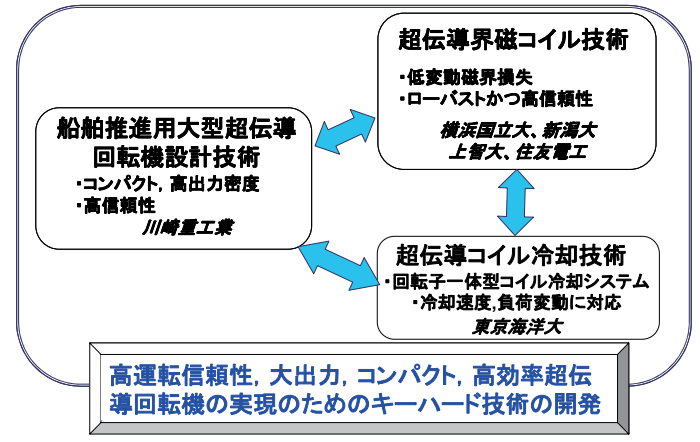

Fig. 4 R\&D of the JST S-innovation project.

最終ステージであるステージIII（アプリケーションの開 発）に取り組んでいる。

\section{4. 研究開発の現状}

\section{1 内航船向け $1 M N / 3 M W$ 高温超電導モ一タの開発}

内航船（国内航路に就航している船）と外航船（国外航 路を就航している船）では船舶のサイズやエンジン出力が 異なるのみならず、その運用方法、波浪・風況等の想定す る環境条件、設計や維持管理に適用する基準も異なってく るため、通常、異なった設計思想が採用される。1〜3 MW 出力の船舶推進用高温超電導モータを開発すれば、 出力ベースでは内航船における大部分の推力レンジがカ バーできることより、当社は、先ず、当該出力範囲の高温 超電導モータの開発を NEDO 事業からの支援を受け、着 手することとした。以下に、その現状を示す。

「船舶用高温超電導モータ内蔵ポッド推進システムの研 究開発」（2007～2009 年度） ${ }^{1,2)}$ で開発した 1 MW 級高温 超電導モータの外観と仕様を Fig. 5 及び Table 3 に示す。

ビスマス系線材を使用した高温超電導コイルをロータ内 部に装着し $30 \mathrm{~K}$ まで泠却後、界磁電流として $200 \mathrm{~A}$ を高 温超電導コイルへ給電し界磁極を構成している ${ }^{3,4)}$ 。界磁 極内には最大 $5 \mathrm{~T}$ の高磁場が発生するため、高温超電導コ イルは非磁性材を巻き芯とする空芯構造を採用している。 また、ステータには通常の銅コイルを用いているが、超電 導界磁コイルからの高磁場に晒されるため、銅コイルを支 持するティース材として非磁性材（ステンレス）を用いる 空芯構造を採用している。これにより、高温超電導コイル が発生する高磁場による大電磁力を大トルクへと有効に変 換することが可能となる。今回の超電導モータで、ステー タの銅コイルの鎖交磁束は最大約 $2 \mathrm{~T}$ であった。超電導状 態を保つためには、超電導コイルを低温維持する温度管理 が不可欠であるが、ここでは、真空断熱を含めた多重断熱 構造により輻射入熱や伝導入熱の極小化をはかっている。 また、冷却システムとしては、循環式の低温へリウムガス 冷却システムを採用し、ロータ入熱に加え通電に伴う発熱 を、低温へリウムガスによりロータ外へ移送し、外部冷凍 


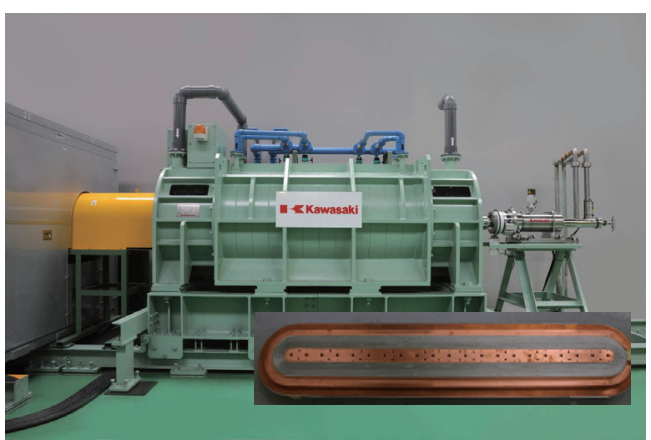

Fig. 5 Photograph of 1 MW-class HTS motor and a superconducting coil (bottom right).

Table 3 Specifications of 1 MW-class HTS motor.

\begin{tabular}{|c|c|c|}
\hline 出力 & (MW) & 1 \\
\hline 回転数 & (rpm) & 190 \\
\hline 相数 & & 3 \\
\hline 極数 & & 4 \\
\hline 電機子電圧 & (V) & 1,200 \\
\hline 高温超電導導体 & & BSCCO-2223 \\
\hline 界磁電流 & (A) & 200 \\
\hline 超電導作動温度 & $(\mathrm{K})$ & 30 \\
\hline 低温冷媒 & & 低温へリウムガス \\
\hline 低温部設計冷却 & 力 $(\mathrm{W})$ & 100 \\
\hline 設計効率 & $(\%)$ & 98（冷却損含む） \\
\hline
\end{tabular}

機により再冷却した後、再び低温冷媒としてロータに圧送 している。この場合、静止部（外部冷却システム）と回転 部（ロータ）間での泠媒（ $25 \mathrm{~K} \sim 30 \mathrm{~K} ）$ の出入りが必要と なるため、低温へリウムガス給排装置と呼ばれる特殊なデ バイスの開発 ${ }^{5)}$ を行った。

本研究開発グループでは、先ず冷却特性の評価と構造成 立性の実証が必要と判断し、1 $\mathrm{MW}$ 出力の高温超電導モー タを実スケールで製作することとした。一方、高温超電導 コイルについては開発予算の制約もあり減数と寸ることと し、対応する部分負荷試験結果を合理的に外挿することで $1 \mathrm{MW}$ 出力の高温超電導モータの特性を推定した。これに より、 $1 \mathrm{MW}$ 機としての設計の妥当性を概略評価した。

最終的には、国内では最高出力となる $450 \mathrm{~kW}$ まで負荷 を上昇させた ${ }^{6}$ 。この時のモータ効率や泠却負荷に対する 計測結果を評価することで、1 MW 機としての設計の妥当 性を確認した。また、定格回転数（190 rpm）での $450 \mathrm{~kW}$ 出力における、24 時間連続運転を行い、ロータ内の低温 部の温度上昇が許容値とした值（1 K）以内で収斂するこ とを確認した。

本プロジェクトでは、提案する「超電導モータ内蔵ポッ ド推進システム」(Fig. 6 参照) に対し、燃費削減効果の 評価を行った。すなわち、CFD 解析や水槽模型試験によ る船舶の推進性能推定、類似船舶での実運航計測デー夕を 総合評価することで、超電導化による燃費削減効果の試算 を行い、プロペラとディーゼル主機が直結した従来推進シ ステムと比較し、超電導モータ内蔵ポッド推進システムで は、16\%以上の燃費削減も可能との検証結果を得た。

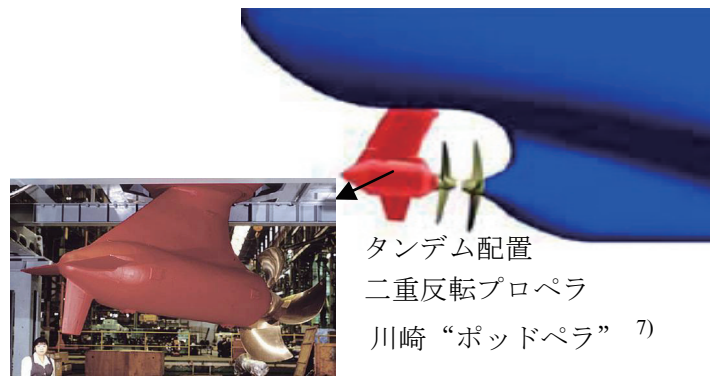

Fig. 6 Podded ship propulsion system.

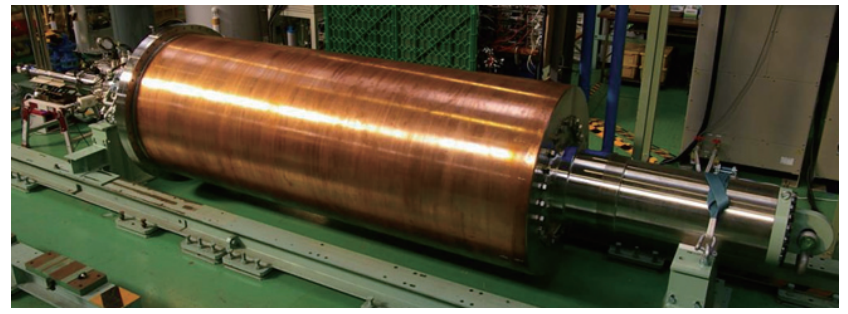

Fig. 7 Cooling and excitation test of the rotor for the 3 MW HTS motor.

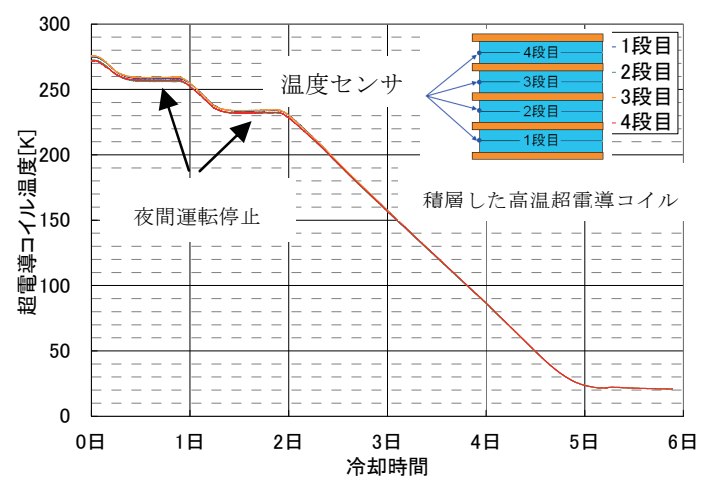

Fig. 8 Temperature vs. time history of the superconducting coil.

引き続く実用化開発フェーズ「船舶用高温超電導モータ 内蔵ポッド推進システム実用化のための研究開発」（2010 〜2012 年度）では、現在、3 MW 出力高温超電導モータ の実用試作機を開発中である。Fig. 7 はロータ単体試験の 状況を示したものである。Fig. 8 には、高温超電導コイル の冷却時の温度時歴を示す。本図を見ると初期の夜間運転 停止期間を除くと約 4 日間において、高温超電導コイル 4 層が $20 \mathrm{~K}$ 均一となるよう泠却が達成されていることがわ かる。その後、 $30 \mathrm{~K}$ までの各温度ステップにおいて超電 導コイルが同様のばらつき範囲の温度分布となるように温 度調整が可能であることを確認した。また、1 極分の超電 導コイルに対し、所定励磁電流である $200 \mathrm{~A}$ までの通電を 行い、そこでの入発熱值が設計許容值を大きく下回ること を確認した。現在、今秋からの $3 \mathrm{MW}$ 高温超電導モータ としての負荷試験に向けて各種準備を行っている。

\section{2 将来の外航船向け大型高温超伝導モータの開発}

将来の外航船向け $20 \mathrm{MW}$ 級大型高温超伝導モー夕に向 けたキーハード技術の開発を JST S-イノベ事業からの支援 を受け実施中である。以下に、その現状を示す。

大型超伝導モータでは、その超伝導コイルに負荷される 
電磁力やその変動成分、超伝導界磁極に蓄積される電磁エ ネルギーが巨大となることから、超伝導コイルのロバスト 性の確保やクエンチを予兆検知した後の適切な保護技術な どが重大な課題となる。超伝導界磁極への電磁シールド (常温ダンパ) は、中小型の超伝導モータでは比較的容易 に製作できるものの、20 MW 級の大型機向けのものとなる と、製造設備等の制約よりその製作は容易ではなく高コス 卜化が避けられない。将来的に電磁シールドを省略するこ とを想定すると、電機子からの変動磁場に対する超伝導コ イルの損失（交流損）のさらなる低減法の開発も必要となっ てくる。大出力機の場合、ロータ径が大きくなるため、 NEDO プロジェクトで製作の超電導モータで採用している冷 媒圧送循環式の超伝導コイル冷却法は必ずしも効率的とは ならない可能性もあり、より効率的でコンパクトな冷却シ ステムが求められる。また、将来の超伝導モータの高性能 化・さらなるコンパクト化に向けて Y 系線材の適用を視 野に入れた研究も必要となるであろう。JST S-イノベ事業 では、これら将来の大型高温超伝導モータにおいて、特に 重要となる課題に対し、要素技術の開発とそれに基づく キーハード技術の開発・検証を行っている。

ステージII（2009～2011年度）では、先ず、20 MW級船 舶推進用超伝導モータの概念設計例えば8)を行った。これによ り総合効率 $99 \%$ を達成しながら、56 $\mathrm{kNm} / \mathrm{m}^{3}$ を超える世界 最高レベルの高トルク密度（単位体積当りのトルク）達成 の見込みを得るとともに、超伝導界磁コイル及びロータ冷 却システムに対する要求仕様を明確化した。Fig. 9は、20 MW級超伝導モータの断面形状の一例であるが、この場 合、超伝導界磁極の左右に200トンを超える電磁力が負荷 されることがわかる。このような電磁力に伴う電磁応力、 機械応力に対しロバストな超伝導界磁コイルを設計するた め、 $\mathrm{Bi}$ 系銀シース線材及び銅安定化Y系線材に対し長さ方 向、及び剥離方向に繰り返し引張り応力を印加した場合の 劣化特性 (Fig. 10参照) や劣化後の交流損 ${ }^{9,10)}$ 等の基礎的 データが取得された。超伝導コイルにおいてクエンチに対

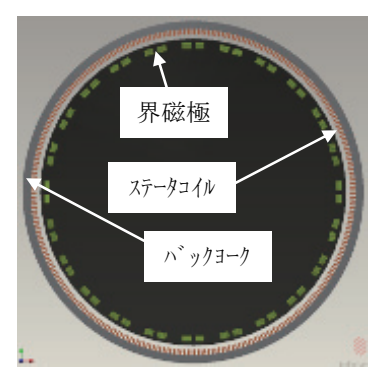

断面構造

20 MW@90 rpm, 24 極機

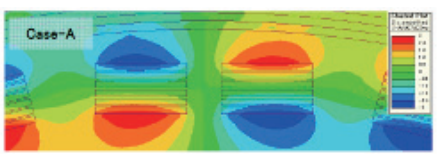

界磁極周囲の磁場分布

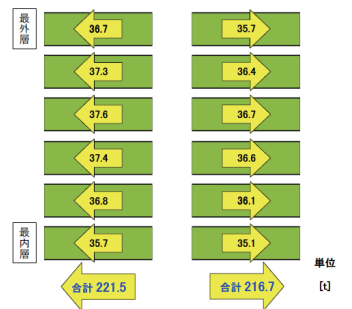

超電導コイルに負荷される電磁力
Fig. 9 Conceptual design of $20 \mathrm{MW}$-class HTS motor.

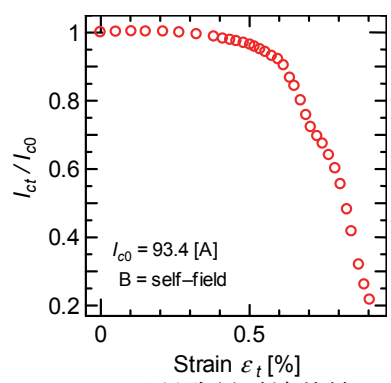

(a) 歪対臨界電流特性

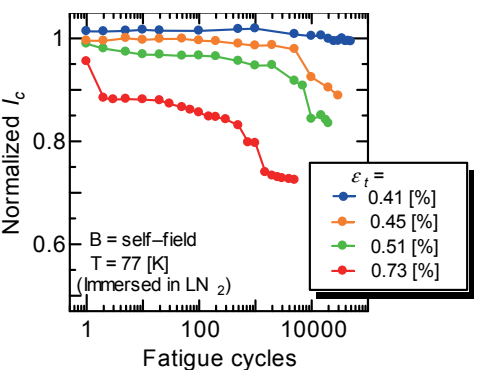

(b) $I_{c t}$ の繰り返し応力特性
Fig. 10 Tensile stress characteristics of copper-stabilized YBCO coated conductor.

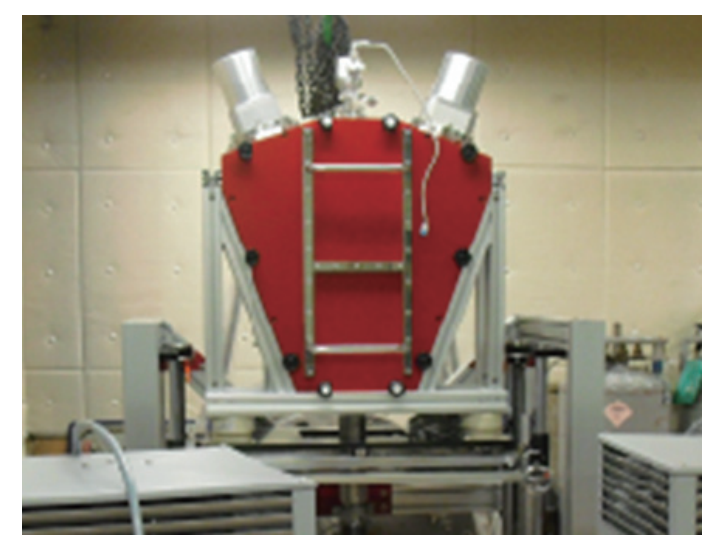

Fig. 11 On-board rotor cooling system based on a thermosyphon with He-Ne mixture.

し損傷を受けないための条件を明らかにするために，クエ ンチを検出しクエンチ保護回路を動作させた後の線材の最 高到達温度が一定のレベル以下に抑制するための条件検討 が行われた。加えて、交流損低減やY系線材の低温特性な ど諸般のデータ収集や検討を行った。また、高効率でコン パクトな冷却システムとして、ロータ一体型ネオンーヘリウ ム混合ガス使用サーモサイフォン方式（Fig. 11参照）の試 作 ${ }^{11,12)}$ がされ、その基本特性が明らかにされた。これらの 研究開発により、ステージIIIに進むにあたり必要となる要 素技術がほぼ完成した。

ステージIII（2012～2013 年度）では、ステージII で得ら れた概念設計や各機関の研究成果に基づき、船舶推進用の $20 \mathrm{MW}$ 級超伝導モータの基本設計を完成させる予定であ る。また、ステージII で確立した要素技術を応用し、20 MW 級超伝導モータに搭載する超伝導コイルのクエンチ特 性やロバスト性を具体的に明らかにしていく予定である。 一方、冷却システムについては、ロータ一体型ネオン-ヘリ ウム混合ガス使用サーモサイフォン方式に対し、ステージ IIにおいて明らかにした基本特性に基づき、本冷却システ ムを $20 \mathrm{MW}$ 級超伝導モータのロータ冷却及び超伝導コイ ル冷却に具体的に適用した場合の被冷却体の応答も加味し た総合的評価を行う予定である。ステージIIIにおいては、 最終的には、20 MW 級超伝導モータを実現するためのキー ハードである超伝導コイル、冷却システム及びロータ構造 
の各々に対し実機スケールもしくは実機を縮尺模擬したア プリケーションモデルを製作し、検証を行っていく計画で ある。

\section{5. 実用化までの道筋}

船舶推進用の高温超電導モータを実用化するまでには、 長期運転時の耐久性評価や波浪等の負荷変動に対する強度 評価・交流損評価が不可欠となる。当社を中心とする研究 開発グループは、メガワット級大型回転機に対して電力回 生を行うことにより省エネルギーで長期試験が可能とな り、かつ任意の荷重時歴が発生可能な試験設備の導入に対 し、経済産業省イノベーション拠点立地支援事業 へ、 「大型超電導回転機等の実証・評価設備」（川崎重工業 (株)、（国）東京海洋大学、（独）海上技術安全研究所） として応募し、採択を受けた。導入予定の設備概要を Fig. 12 に示す。2012 年度中には本試験設備の導入を完了し、 2013 年度からの本格稼動を予定している。先ずは、NEDO 事業で開発した $3 \mathrm{MW}$ 高温超電導モータの長期運転や各種 運転モードに対する耐久性評価に適用することで、船舶推 進用高温超電導モータの完成度を高める予定である。

また、船舶推進用の高温超電導モー夕を実用化するため には、最終的には船内に搭載し、実海域上で性能確認を行 うことが不可欠となる。一方、船舶搭載時に想定される大 部分の運転モードに対する高温超電導モータの応答につい ては、前述の「大型超電導回転機等の実証・評価設備」を用 いれば、陸上試験段階においても実証・評価が可能となる であろう。そのため、実船試験においては、船舶の動摇や スラミング等の船底衝撃に対する応答、船内への搭載性や メンテナンス性の確認等、船内でしか評価・確認が困難な 事象に限定して確認・評価を行うことで、船舶推進用超電 導モータとしての完成と実用化を目指すことが効率的とな るであろう。

\section{6. まとめ}

本テーマ解説では、船舶推進用の高温超電導モータの実 用化に向けて当社が参画している NEDO 省エネルギー革新 技術開発事業、JST 戦略的イノベーション創出推進事業 （S-イノベ）について、その目的・位置づけを紹介すると ともに、当社の開発の現状を示した。また、船舶推進用の 超電導モータの実用化までの道筋について所見を述べた。 NEDO 省エネルギー革新技術開発事業については、本年度 が 3 カ年計画の最終年度となり、今秋には $3 \mathrm{MW}$ 高温超電 導モータの負荷試験を予定している。また、JST 戦略的イ ノベーション創出推進事業（S-イノベ）においても、本年 度より最終ステージであるステージIIIがスタートしてお り、より実用化に近い研究開発とアプリケーションモデル の試作が求められている。当社としては、これら事業を成 功させるとともに、船舶推進用高温超電導モータの早期

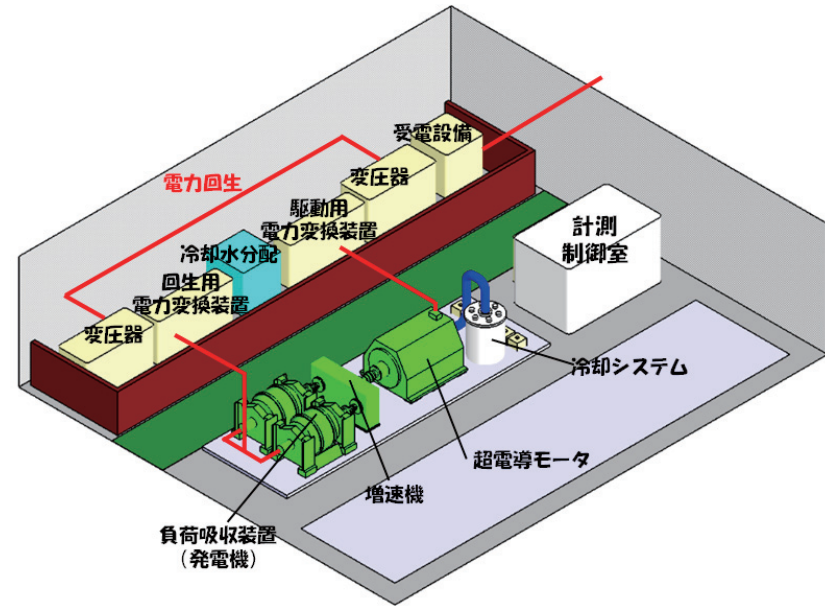

Fig. 12 Land-based full-power test facility for superconducting rotating machines.

実用化に向けて、鋭意努力していく所存であり、関係各位 のより一層のご支援・ご協力を希望する次第である。

本稿をまとめるにあたり、住友電気工業株式会社 超電 導製品開発部 応用開発部部長 - 林和彦氏、東京海洋大学 教授 - 和泉充氏、海上技術安全研究所専門研究員 - 沼野正 義氏、上智大学客員教授 - 塚本修巳氏、上智大学教授 - 高 尾智明氏、新潟大学准教授 - 福井聡氏、横浜国立大学准教 授・藤本康孝氏、株式会社超電導機構 代表取締役 奥村 嘉賀男氏等のプロジェクト関係者には大変有益なご意見を 賜りましたことを、心より感謝いたします。

\section{参 考 文 献}

1) K. Umemoto, K. Aizawa, M. Yokoyama, K. Yoshikawa, Y. Kimura, M. Izumi, K. Ohashi, M. Numano, K. Okumura, M. Yamaguchi, Y. Gocho and E. Kosuge: "Development of 1 MW-class HTS motor for podded ship propulsion system," J. Phys.: Conf. Ser. 234 (2010) 032060

2) 梅本勝弥、合澤清志、横山 稔、小野寺達也、和泉 充、沼 野正義、奥村嘉賀男:「メガワット級船舶推進用超電導モー タの開発」, マリンエンジニアリング学術講演会講演論文集 81（2011）103-104

3) S. Yuan, Y. Kimura, M. Miki, B. Felder, K. Tsuzuki, T. Ida, M. Izumi, K. Umemoto, K. Aizawa and M. Yokoyama: "Development of a field pole of 1 MW-class HTS motor,” J. Phys.: Conf. Ser. 234 (2010) 032067

4) Y. Koshiba, S. Yuan, N. Maki, M. Izumi, K. Umemoto, K. Aizawa, Y. Kimura and M. Yokoyama: "Critical current and electric loss under magnetic field at $30 \mathrm{~K}$ on $\mathrm{Bi}-2223$ superconducting coil for ship propulsion motor," IEEE Trans. Appl. Supercond. 21 (2010) $1127-1130$

5) E. Kosuge, Y. Gocho, K. Okumura, M. Yamaguchi, K. Umemoto, K. Aizawa, M. Yokoyama and S. Takao: "Development of helium transfer coupling of $1 \mathrm{MW}$-class HTS motor for podded ship propulsion system," J. Phys.: Conf. Ser. 234 (2010) 032032 
6) 川崎重エプレスリリース、「メガワット級超電導モータで国 内最高出力達成一高効率の電気推進船の実現に向けて一」 (2010.11.1)

7) 吉川啓一、舩野 功、大西 廣、高須順三、日野満伸:「新 型舶用電気推進機「ポッドペラ」の開発」, 川崎重工技報 155 (2004.5)

8) S. Fukui, M. Takahashi, T. Kawai, J. Ogawa, T. Oka, T. Sato and O. Tsukamoto: "Numerical study of optimization design of high temperature superconducting field winding in $20 \mathrm{MW}$ synchronous motor for ship propulsion," 22nd International Conference on Magnet Technology, Marseille, France (2011)

9) T. Uno, T. Ojima, S. Matsui, T. Takao and O. Tsukamoto: "AC magnetization losses in copper-stabilized YBCO coated conductors subjected to repeated mechanical stresses," IEEE Trans. Appl. Supercond. 21 (2010) 3257-3260

10) R. Honzawa, T. Ojima, T. Noda, T. Uno, T. Takao, T. Tsukamoto, Y. Iida, T. Ogino and O. Tsukamoto: "Relation between dependence of AC transport current losses in YBCO coated conductors on repeated mechanical stresses and cracks in the superconductor layers caused by stresses," 22nd International Conference on Magnet Technology, Marseille, France (2011).

11) B. Felder, M. Miki, Z. Deng, K. Tsuzuki, N. Shinohara, H. Hayakawa and M. Izumi: "Development of a cryogenic heliumneon gas mixture cooling system for use in a Gd-bulk HTS synchronous motor,” IEEE Trans. Appl. Supercond. 21 (2011) 2213-2216

12) B. Felder, M. Miki, K. Tsuzuki, N. Shinohara, H. Hayakawa and M. Izumi: "A 100-W grade closed-cycle thermosyphon cooling system used in HTS rotating machines," Cryogenic Engineering Conference \& Int. Cryogenic Materials Conference (CEC-ICMC) (2011)

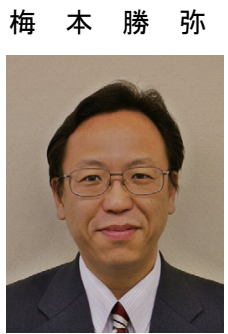

1967 年 6 月 14 日生。1992 年大阪大学大学 院工学研究科博士前期課程造船学専攻修了。 2001 年大阪大学大学院工学研究科博士後期課 程地球総合工学専攻修了、1992 年より川崎重 工業株式会社技術研究所勤務。船体構造の研 究開発、舶用推進器の研究開発に従事、2007 年より超電導モータの開発を担当、船舶海洋 工学会、日本機械学会会員、工学博士。

柳 本 俊之

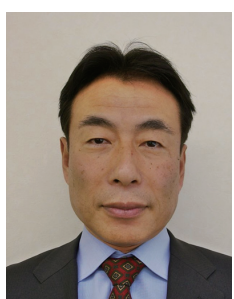

1955年9月 10 日生。1981年大阪府立大学工 学研究科修士課程修了。1981年より川崎重工 業株式会社技術研究所勤務。2012年より同所 副所長。スターリングエンジン、医療機器開 発に従事。その後、トライボロジー技術開発 （エンジン、ガスタービン、油圧機器）に従 事し、現在は超電導モータ等の先進技術開発 推進担当。日本機械学会会員。 